\title{
Donald Trump's Use of Dysphemism for Mass Persuasion
}

\author{
Islam Muhammad *
}

\section{Introduction}

Mr. Trump's victory in the 2016 US Presidential Election prompted a torrent of criticism around the world and, in the words of the former French President François Hollande, precipitated "a period of uncertainty" (AFP, 2016). Much of this criticism has its roots in Mr. Trump's strongly negative language. Mr. Trump was criticized for his disparaging language which was described by Flegenheimer and Barbaro (2016, para.1) as going against "long-held ideals of American democracy" and by Dubrofsky (2016, p.663) as lacking "controlled and civil behavior". Indeed, Mr. Trump's use of strongly negative language when addressing political topics, the media, and his political opponents is noteworthy.

Mr. Trump's strong rhetoric led politicians to expect his loss in the presidential election. There was a general belief among politicians and the US media that the American voter who elected Barack Obama to be President largely acted because of his "inclusive rhetoric" (Jenkins and Cos 2012, p.185), and would not vote for Mr. Trump because of his divisive language. However, against most expectations and opinion polls, Mr. Trump won the exit polls with more votes from people of color than the more moderate GOP candidate Romney (NBC Exit Polls, 2016). Although politicians regarded Mr. Trump's strong rhetoric as negative, it does not seem to have alienated enough voters to lead to his defeat. Hence, it is worthy of study.

This paper attempts to answer the question: "How did Donald Trump employ negative rhetoric during his campaign to win the presidency?" This paper argues that Mr. Trump's negative use of language, i.e., dysphemism, was intentionally employed as an overt propaganda technique to persuade the voters and win the elections by establishing of the "politics of fear" (Wodak 2016, p.2) - an approach which requires establishing fear in voters as a means of persuading them to take actions based on emotion rather than reasoning.

According to Allan and Burridge (2006), speakers use dysphemism "to talk about people and things that frustrate and annoy them, that they disapprove of and wish to disparage, humiliate and degrade [and] are therefore characteristic

* ELI, King Abdulaziz University, Jeddah, Saudi Arabia.

Cairo Studies in English - 2020(1): https://cse.journals.ekb.eg/ 
of political groups and cliques talking about their opponents." (p.31) This means that using dysphemistic expressions can serve as a propaganda technique in political discussion. Indeed, Hughes (1998) argued that violent language serves as an overt propaganda technique to support or attack ideologies. Similarly, Jowett and O'Donnell (2012, p.303) argued that "propaganda uses language that tends to defy a cause and satanize opponents". This paper thus argues that Mr. Trump attacked the political correct use of language, i.e.; euphemism, which Burridge (2006, p.455) described as being a characteristic of Western social organizations' rhetoric, and employed dysphemism as a means of overt propaganda, a technique that made him attract more media attention than any other candidate (Dubrofsky 2016, p.664; Hearn 2016, p.257) to persuade voters and win the election. The same technique was used by leaders such as Winston Churchill to win wars (Crespo-Fernández, 2013), and by terrorist groups recruiting people to destroy and kill (Naines and O'Shaughnessy, 2014). This paper contends that Mr. Trump's raised fears among voters by using dysphemistic expressions that denigrate his opponents as a persuasive propaganda technique; Wodak (2006) argued that all right-wing populist parties create the "politics of fear" which involves constructing the 'other' as a danger and a threat to 'us' so as to gain public approval and votes.

Thus, in analyzing dysphemism in Mr. Trump's rhetoric, this paper provides some explanations of how he was successful in winning supporters, despite being severely criticized. It also sheds light on the dividing nature of dysphemism that Burridge (2006, p.458) described as standing "at the top of the scale of severity" among discriminatory vocabulary.

Dysphemism, compared to euphemism, has received little attention in the study of political language (Crespo-Fernandez 2013, p.312), and the term itself "rarely appears in ordinary language" (Allan and Burridge 2006, p.29). In addition, most analyses of Mr. Trump's negative language have been political and media studies (see Lynch, 2017; Dubrofsky, 2016; Hearn, 2016) or have approached psychologically the negative use of language as a personality trait (see McAdams, 2016). To the best of my knowledge, this paper is the first to tackle dysphemism as a persuasive technique in Mr. Trump's rhetoric from a discursive analytical perspective. The political discourse analysis approach has been highly recommended by researchers, such as van Dijk (1997, p.12), who strongly supported the application of discourse analysis to political discourse "to answer genuine and relevant political questions and deal with issues that are discussed in political science". Thus, this paper, focusing on an ongoing issue in the political arena, argues that Mr. Trump intentionally employed dysphemism 
as a propaganda tool to delegitimize and humiliate opponents with the goal of persuading voters to vote for him for US President.

The present paper is organized as follows. It begins with the definition of dysphemism and its role as a propaganda technique. Then it highlights the data collected and the theoretical basis for the analysis. After that, the types of dysphemistic expressions in the data and their roles are analyzed. The conclusions and results are reported at the end.

\section{Definition of Dysphemism and its Link to Propaganda}

Allan and Burridge (2006) defined dysphemism in light of the theory of politeness proposed by Lakoff (1973). They stated that "dysphemism is a word or phrase with connotations that are offensive either about the denotatum and/or to people addressed or overhearing the utterance" (p.42), i.e., it refers to taboo words that are used to degrade and offend people. They argued that dysphemism is "characteristic" of political groups when talking about their opponents. This is best explained in light of Brown and Levinson's (1987) work on politeness. Brown and Levinson (1987) argued that the speaker can damage the interlocutors' self-image if they use positive face-threatening acts that insult. Dysphemism is in this category. This makes dysphemism a powerful persuasive tool in political propaganda. This is because, as O'Shaughnessy (2004, p.39) stated, "emotion is the core of propaganda", and dysphemism would help one party destroy the reputation and self-image of the "other" by using negative expressions that bluntly insult to move voters emotionally against the opponents (van Dijk 1995, 1998, 2006).

Allan and Burridge (2006) further argued that dysphemism depends on context. They explained that "dysphemism is not necessarily a property of the word itself, but of the way it is used." (p.62) Thus, a word, such as "Asian" can be neutral or offensive, i.e., dysphemistic, depending on the context in which it is uttered, and the interlocutors involved. This suggests that dysphemism is a deliberate act, especially when used in political speech, and "affects the perception of both the denotatum and the speaker" (Bagasheva 2012, p.158). This deliberateness is at the core of propaganda, which is defined by Jowett and O'Donnell (2012, p.7) as "the deliberate, systematic attempt to shape perceptions". This is the exact aim of this paper: to show how Mr. Trump deliberately used dysphemism as a propaganda technique in his attacks on the media and politicians and to damage his opponents and win supporters. 


\section{Data and Theoretical Framework}

This paper relates to Political Discourse Analysis (PDA). According to van Dijk (1997), PDA "answer[s] genuine and relevant political questions and deal[s] with issues that are discussed in political science." (p.12) The aim of the present paper is to investigate the use of dysphemism in Mr. Trump's speeches as a persuasive rhetoric tool in one of the most controversial US presidential campaigns of all time.

Political Discourse comes under the general umbrella of CDA studies that "deal with the reproduction of political power, power abuse or domination through political discourse" (van Dijk 1997, p.11). It is concerned with the discursive tools used by politicians in political contexts to deliver hidden messages, manipulate the masses, and, in many cases, polarize the people. This paper employs a micro-analysis of nouns, adjectives and verbs to study $\mathrm{Mr}$. Trump's use of dysphemistic expressions in his campaign to exert his influence on the people and to dehumanize and delegitimize his opponents in order to win the election.

To identify the dysphemistic expressions in Mr. Trump's political speeches, the paper uses the framework presented by Allan and Burridge (2006). Simply stated, dysphemism is speaking offensively, and it is the opposite of sweet talk, or euphemism. Examples of dysphemistic expressions are curses, name-calling, and derogatory comments. These expressions play an important role as persuasive tools in political propaganda. They identify marked behavior; that is, being offensive and blunt is "readily determined". This is also related to Fowler's (1991) concept of categorization which involves the use of synonyms or quasisynonyms to label people or activities ideologically. The use of dysphemism is motivated by fear, hatred, and contempt so it applies to van Dijk's concept of "ideological squaring," according to which politicians tend to dehumanize and delegitimize their opponents using offensive terms. It also depends on the context, time, and place. This paper analyzes the use of these expressions in Mr. Trump's speeches to reveal his designated divisive political propaganda approach to campaigning for the President of the United States.

The data collected depends on themes or topics, rather than on one specific speech. According to Hearn (2016, p.657) Mr. Trump promoted himself by constantly repeating rhetoric that breaks the rules of politics. Indeed, he gave dozens of speeches and interviews during his campaign, but he was especially remembered for his constant expression of negative opinions regarding the media and his political opponents. So, to analyze his use of dysphemistic expressions, speeches were selected based on topics related to his political opponents and the media, which were raised by Mr. Trump repeatedly during 
the one-year period of his presidential campaign (2015-2016). Based on these criteria, six speeches were chosen as a representative sample for analysis. The speeches chosen for analysis are:

1. Presidential Announcement (June 16, 2015)

2. GOP Debate (August 6, 2015)

3. Hilton Head speech (December 30, 2015)

4. National Security speech (June 13, 2016)

5. Immigration speech (August 31, 2016)

6. Responding to Assault Accusations speech (October 13, 2016)

This paper is thus not comprehensive. Mr. Trump made many speeches during his presidential campaign. This paper focuses on only six speeches, which cover most of the themes raised by Mr. Trump, rather than a full account of his rhetoric. Due to the limited amount of data, the analysis cannot be quantitative. Therefore, the analysis is mainly qualitative. Limited data is a tradition of qualitative research (Cresswell 2014, p.239). Despite this, the sample of speeches selected for analysis offers a significant account of the use of dysphemistic expressions by Mr. Trump as a campaign technique that contributed significantly to his victory. According to Cresswell (2014, p.239), qualitative research is different from quantitative research in that it can use purposeful sampling to understand the problem and answer the research questions.

\section{Data Analysis Procedure}

This paper adopts a micro-analysis approach in analyzing the six selected speeches (see van Dijk 1993, p.261). In a micro-analysis approach, a linguistic choice is intentionally determined by the speaker to convey specific messages and hence conforms to the deliberate nature of dysphemism and propaganda. It denotes that the selection of one language item indicates the exclusion of some others (Fairclough 1995, p.210). To analyze dysphemism in Mr. Trump's language, six speeches were selected as a representative sample. The speeches selected were already transcribed on the internet. Key language dysphemistic language items: nouns, adjectives, and verbs were highlighted and analyzed in light of the frameworks of Allan and Burridge's (2006), Fowler's (1991) concept of categorization, and van Dijk's (1995) “ideological squaring”. Conclusions on Mr. Trump's use of dysphemism and its role in raising fear among voters as a persuasion technique are discussed. 


\section{Analysis of Dysphemistic Expressions in Donald Trump's Speech}

Dysphemistic expressions come under the more general label of 'loaded language' or what Hayakawa (1972) called 'snarl words' and what Bolinger (1980) called 'epithets.' 'Snarl words' or 'epithets' are overtly biased negative words that aim at producing a negative emotion in the audience in order to direct them to take a certain action. According to Wodak (2016), a right-wing populist party creates fear in the voters as a persuasion technique. It could be a fear of losing one's job, a fear of strangers, or a fear of immigrants, as well as a fear of corrupted mainstream media and politicians. Indeed, Mr. Trump's use of dysphemistic expressions is a typical propaganda technique of a right-wing populist party. The analysis below shows his emotive negative language when discussing topics related to the US as a country on the decline, on Barack Obama and Hillary Clinton as corrupt political opponents and, finally, on the media as a biased institution. Analysis is performed on the use of dysphemistic verbs, nouns, and adjectives.

\subsection{Dysphemism about the US}

Mr. Trump's speech in which he formally announced his candidacy to be the Republican nominee for President starts with invoking a fear of a US in decline. Mr. Trump uses a set of emotive negative words to describe the US as a failing country in order to provoke voters' feelings of nationalism and hatred toward people responsible for destroying their own country. This is established by using several emotive verbs, such as kill, beat, and lost, among others. These verbs show the US as a defeated country while, at the same time, making other agents responsible for this decline. The result is hatred toward these agents on the part of Americans. This is displayed in the examples below:

1. They (China) kill us. (Presidential Announcement)

2. They (Japan) beat us. (Presidential Announcement)

3. They (Mexico) are killing us. (Presidential Announcement)

4. We lost thousands of lives. (Presidential Announcement)

Examples (1) and (3) show Mr. Trump's use of the emotive transitive verb kill to present the utmost threat to people, namely threatening their lives. It describes how other countries are defeating the US. The verb is intended to instill fear in voters, and the subject position together with the active voice makes China and Mexico directly responsible for threatening Americans' lives. Fowler (1991) argued that writers use passive voice to hide agency but use active voice to hold an agent responsible for actions. Fowler added that the use of a transitive verb shows the affected object, or patient. Thus, Mr. Trump holds China and 
Mexico responsible for defeating Americans, and presents this idea in the present tense and active voice to show continuity. If the audience perceives the verb kill figuratively (to punish severely) or informally (to destroy or eradicate), they are similarly threatened because both meanings raise fear of and hatred for the agents, China and Mexico. Similarly, the verb beat (to strike repeatedly, defeat. or punish) in example (2) raises negative emotions among the audience, but this time against Japan. In Example (4), the emotive verb lost in the past tense establishes the fact that the Americans are already defeated. Thus, the use of dysphemistic emotive verbs by Mr. Trump services his propaganda techniques of raising fear and hatred among the voters with the intended result being to persuade them to vote him for President.

Mr. Trump, in the rest of his campaign speeches, continues to employ a set of loaded adjectives followed by nouns (adjective + noun) to describe the US as a failing nation and to establish it as a fact. In the examples below, the US is referred to as being in 'serious trouble'; its military is 'depleted'; its labor participation rate is 'horrible'; and its airports are 'disastrous'.

5. Our country is in serious trouble. (GOP Debate)

6. Don't forget building up our depleted military. (Immigration speech)

7. (The US has a) horrible labor participation rate. (Presidential Announcement)

8. We have all of these disastrous airports. (Presidential Announcement)

The use of emotive adjectives in examples (5), (6), (7) and (8) show the US in a negative light. This dysphemistic representation of the US as a failing country has negative effects on the receivers of the information. This is emphasized by van Dijk (2000, p.34) who stated that "negative topics have negative consequences in the minds of the recipients". The receivers, or voters, in this case, feel the danger that their country is facing. This hatred must find a scapegoat, or a responsible agent to blame (Wodak, 2016). Trump puts the blame on his political opponents and the media to delegitimize them and win the voters. The following section includes an analysis of Mr. Trump's use of dysphemistic expressions directed against his opponents.

\subsection{Dysphemism on Obama}

Mr. Trump uses dysphemistic adjectives to blame President Barack Obama for the US being in decline. The adjectives negative, stupid, bad, incompetent, corrupt are employed by Mr. Trump to describe President Obama. These adjectives deliver a negative message to the voters; viz., President Obama is referred to as being corrupt and incompetent. These adjectives are overtly biased 
and require the audience to react negatively. They represent the category of words which Bolinger (2014) called 'epithets'-words that bluntly show bias so all people can see it.

9. He (Obama) was actually a negative force. (Presidential Announcement)

10. How stupid are our leaders? (Presidential Announcement)

11. He's (Obama) a bad negotiator. (Presidential Announcement)

12. It's an incompetent administration. (National Security speech)

13. Replace (...) our current corrupt administration. (Immigration speech)

These examples are overtly biased and negative and require the audience to establish Democrats as incompetent and hence to feel the need to choose a more skillful Republican, i.e., Mr. Trump. The adjective corrupt in example (13), however, delivers a deeper negative meaning. The Obama administration is not just incompetent, but also, in Mr. Trump's words, corrupt. The emotive biased adjective corrupt displays President Obama as guilty of dishonest practices.

Mr. Trump's weapon of loaded language is also directed against Obamacare. He describes it with negative nouns, such as disaster, lie, and catastrophe. Bolinger (2014, p.77) argued that, like adjectives, "there are overtly biased nouns" that insult. Thus, Mr. Trump uses nouns that are hyperbolic to exaggerate his bias against Obamacare. According to Claridge (2011, p.12), hyperbole is used by speakers to "heighten the force of the proposition and mark the intensity of speaker involvement and commitment". Thus, Mr. Trump's emotional involvement strengthens his attack and is a very persuasive technique. In addition, Mr. Trump adds a number of dysphemistic adjectives to intensify the hyperbolic nouns and thus the force of his utterances in big lie, a complete disaster and total catastrophe. This use of intensifying adjectives in examples (14), (15) and (16) below is dysphemistic and hence adds to the emotional force of Mr. Trump's argument and its persuasive effect on the audience.

14. We have a disaster called the big lie: Obamacare. (Presidential Announcement)

15. It's (Obamacare) a complete disaster. (GOP Debate)

16. Obamacare is a total catastrophe. (Hilton Head speech)

Thus, Mr. Trump uses several hyperbolic nouns accompanied by negative adjectives to strengthen the negative force of the utterance and to create the dysphemistic effect on the perception of Obamacare. Also, the use of nouns related to death and torture is significant, viz., they create a paradox. Obamacare which should provide health services to Americans and save their lives is, to Mr. 
Trump, deadly. Thus, in creating such a contrast, he can represent it negatively and to persuade the voters to end it. Similar techniques are used in the following section to show Mrs. Clinton as a corrupt politician unworthy of becoming President.

\subsection{Dysphemism on Hillary Clinton}

Mr. Trump, in his attempt to disparage Mrs. Clinton, describes her as bad, crooked, corrupt and horrible. These emotive and evaluative adjectives are overtly biased. They directly describe Clinton as a corrupt old person who cannot be President; see the examples below:

17. She (Clinton) is crooked. (Responding to Assault Accusations speech)

18. She (Clinton) is horrible. (Hilton Head speech)

19. She (Clinton) will make a bad president. (National Security speech)

20. She (Clinton) has a corrupt control over our government. (Responding to Assault Accusations speech)

Another significant use of these adjectives is that Mr. Trump came to associate them as a naming convention or a label for Mrs. Clinton. He later calls her "Crooked Hillary Clinton'. This attributive adjective, according to Halliday and Matthiessen (2004), is used to describe something which is already shared by the audience. It is not new information; it is given information. This makes people associate being crooked with Mrs. Clinton, which is a very persuasive technique for humiliating her.

Moreover, Mr. Trump uses a few loaded verbs to delegitimize Mrs. Clinton's actions. Like nouns and adjectives, verbs can be biased and dysphemistic, especially when they overtly express the attitude of the speaker towards others (Bolinger, 2014). In the following examples, the verb lack shows incompetency and the verbs trigger and support show the disastrous consequences for Americans if they choose Mrs. Clinton to be President. These claims are not based on evidence, but emotion. That is, they appeal to pathos, which is based on making an appeal that is based on emotion in order to persuade. See the examples below:

21. She lacks the temperament and integrity to be president. (National Security speech)

22. She supports policies that bring the threat of radical Islam. (National Security speech)

23. She does not have the strength or the stamina to make America great again. (Immigration speech) 
24. Clinton's plan would trigger a constitutional crisis unlike anything we have seen before. (Immigration speech)

These verbs make an analogy between Clinton's actions and decisions regarding radical Islam and crisis, which makes people afraid of her. Similarly, Mr. Trump employs a set of negative nouns to refer to Mrs. Clinton and her husband in the following examples:

25. She supports policies that cause so much damage. (National Security speech)

26. She will be a disaster. (Immigration speech)

27. The result of her (Clinton's) misconduct was the release of thousands and thousands of dangerous criminal aliens. (Immigration speech)

28. The Clintons are criminals. (Responding to Assault Accusations speech)

These negative nouns overtly set Mr. Trump's bias against Mrs. Clinton and her husband. They ingenuously show his prejudice against them. This overt stance works as a persuasion technique, especially when no tangible evidence is provided. It is very unlikely that a criminal will be running for President of the US. The audience knows that, in calling Mrs. Clinton and her husband criminals, Mr. Trump is exaggerating, but they accept this overstatement. This is related to what Shabo (2008, p.117) argued about propagandists who "evoke fear in people they want to manipulate". Because people are afraid, they come to digest what Mr. Trump claims without questioning it and by hearing these claims repeatedly, they become reality in the minds of listeners.

\subsection{Dysphemism on the Mainstream Media}

Mr. Trump presented the media as another manifestation for the so-called failing US. The media, according to Mr. Trump, is a corrupt organization that benefits at the expense of the American people. He describes the media as vicious, preposterous, ludicrous, false, fraud, slanderous, horrible, ridiculous, bad, corrupt, wild, malicious, hurtful, egregious, crooked, and disgusting. This set of dysphemisms categorizes the media as evil. This is related to what Fowler et al. (1979) and Fowler (1991) called 'categorization', which involves the use of excessive negative terms to label something as bad. These adjectives are characteristically negative. Volek (1987) argued that the basic meaning of these adjectives is inherently negative, and their connotation does not change over time. Thus, they deliberately insult. This is also related to van Dijk's (1995) notion of "ideological squaring" which involves categorizing the media as bad to delegitimize it. This reveals that Mr. Trump's dysphemistic expressions have 
negative denotatum meaning and are intentionally humiliating. The effect of this technique is that people come to categorize the media as vicious and stop believing whatever information they get from reporters.

Among all his opponents, the media was the most negatively represented organization in Mr. Trump's speeches. These accusations and negative descriptions were intended, as Hearn (2016) described, to draw the media's attention and as a propaganda technique like the one used in reality TV. Hearn (2016, p.657) said that presidential candidates are running political campaigns "while Trump is running the media". Similarly, Dubrofsky $(2016$, p.17) stated that "neither of these candidates have attracted the same media attention as Trump" because of his use of crass language or dysphemism.

Mr. Trump's language is thus remarkably politically incorrect ${ }^{1}$, or dysphemistic. He himself directly attacked "politically correct" use of language when he said "I think the big problem this country has is being politically correct. I've been challenged by so many people and I don't, frankly, have time for total political correctness" (Trump, 2016, Line). His strong rhetoric can be debated as characteristic of the right-wing populist rhetoric which Wodak $(2016$, p.2) described as aiming at constructing scapegoats and enemies (e.g. minorities) to raise voters' fears. Thus, voters, out of fear, choose tough people who can eliminate the threats. Wodak (2016, p.5) argued that right-wing populist politicians "create fear and legitimize their policy proposals (...) with an appeal to the necessities of security". By analogy, Mr. Trump described himself many times as tough, and promised the voters that he would be tough to persuade them to choose him to end the claimed threats. Tabe 1 summarizes the results; it displays Trump's dysphemistic expressions and their typology.

Table 1. Summary of Trump's dysphemistic expressions and their classification

\begin{tabular}{|l|l|l|}
\hline \multicolumn{1}{|c|}{ Category } & \multicolumn{1}{|c|}{ Dysphemistic Terms } & \multicolumn{1}{c|}{$\begin{array}{c}\text { Examples form } \\
\text { Trump's Speeches }\end{array}$} \\
\hline Emotive Verbs & kill-beat-lose-lack-trigger & $\begin{array}{l}\text { They (China) kill us } \\
\text { They (Japan) beat us. } \\
\text { We lost thousands of lives }\end{array}$ \\
\hline Emotive Adjectives & $\begin{array}{l}\text { preposterous-ludicrous-false } \\
\text { fraud-slanderous-horrible- } \\
\text { ridiculous-wild-malicious-hurtful- }\end{array}$ & $\begin{array}{l}\text { How stupid are our } \\
\text { leaders? } \\
\text { She (Clinton) is crooked. }\end{array}$ \\
\hline
\end{tabular}

${ }^{1}$ Political correctness is used here as synonym for euphemism, as Burridge (2006) argued that political correctness is a synonym to euphemism because, like euphemism, it protects the hearer's face by using appropriate naming and polite addressing. 


\begin{tabular}{|c|c|c|}
\hline & $\begin{array}{l}\text { egregious-crooked-disgusting- } \\
\text { stupid }\end{array}$ & \\
\hline $\begin{array}{l}\text { Emotive Adjectives plus } \\
\text { Nouns }\end{array}$ & $\begin{array}{l}\text { serious trouble-depleted military- } \\
\text { horrible labor- disastrous airports- } \\
\text { negative force-bad negotiator } \\
\text { incompetent administration- } \\
\text { corrupt administration- big lie bad } \\
\text { president -corrupt control }\end{array}$ & $\begin{array}{l}\text { Our country is in serious } \\
\text { trouble. } \\
\text { He (Obama) was actually a } \\
\text { negative force. } \\
\begin{array}{l}\text { Obamacare is a total } \\
\text { catastrophe. }\end{array}\end{array}$ \\
\hline Emotive Nouns & Disaster-misconduct -criminals & The Clintons are criminals. \\
\hline
\end{tabular}

\section{Conclusion}

The analysis of dysphemism in President-Elect Donald Trump's speeches reveals how he skillfully employed negative language as an overt propaganda technique to delegitimize and destroy his opponents and, thus, win the election. It is obvious that Mr. Trump, a reality TV superstar, is aware of the role language can play in persuading people. He employs dysphemism to emotionally move the voters to take a course of action. These results agree with recent media studies that suggested Mr. Trump's skillful manipulation to draw the attention of the media (Dubrofsky 2016; Hearn 2016).

The present paper shows that Mr. Trump's rhetoric is typical of right-wing populist politicians who adopt fear as a promotional technique for their political propaganda. Mr. Trump employs a set of loaded language represented in his use of dysphemistic adjectives, nouns and verbs to humiliate and disparage his opponents. This is in addition to repeating these insults as a technique which makes them very powerful evaluative and persuasive tools.

In conclusion, Mr. Trump uses violent emotive language as a mass persuasion technique to attack his opponents. However, in attacking political correctness and in using wartime propaganda rhetoric; i.e., dysphemism, his character has come under scrutiny. This is best explained by the following quotation from Burridge (2006, p.461):

When people without 'natural cover' (euphemism) express themselves in an 'incorrect' way, there is always the danger that their audience will judge them on what is known about the character of others who have spoken in a similar way, and this can mean true 
racists, true homophobes, true misogynists whose motives are malevolent".

Indeed, Mr. Trump was called a "bigot and racist" (Milbank 2015, para1). Such racist representations when attached to the President of the US may only have divisive results and provoke more radical reactions as represented in the current revival of Nazi slogans and radical movements across Europe and the US. Hence, though Mr. Trump managed to become the US president through his successful use of dysphemism as propaganda tool, his technique has resulted in the rise of radical ideologies that may have very negative consequences and introduce a time of uncertainty.

\section{References}

Allan. K., \& Burridge, K. (2006). Forbidden words: Taboo and the censoring of language. Cambridge: Cambridge University Press.

Agency France Press (2016, November 9). Trump win 'opens period of uncertainty': France's Hollande. Retrieved from http://www.france24.com/

Bagasheva, A. (2012). The tastes and distastes of verbivores-some observations on X-phemisation in Bulgarian and English. Lexis, 7, 157-191. doi: 10.4000/lexis. 390

Baines, P., R., \& O'Shaughnessy N., J. (2014). Al-Qaeda messaging evolution and positioning, 1998-2008: Propaganda analysis revisited. Public Relations Inquiry, 3(2) 163-19. doi: 10.1177/2046147X14536723

Bolinger, D. (2014). Language - the loaded weapon: The use and abuse of language today. London: Routledge.

Brown, P., \& Levinson, S., C. (1987). Politeness: Some universals in language use. Cambridge: Cambridge University Press.

Burridge, K. (2006). Taboo, euphemism, and political correctness. Encyclopedia of Languages \& Linguistics, 455 - 462.

Claridge, C. (2011). Hyperbole in English. A corpus-based study of exaggeration. Cambridge: Cambridge University Press.

Crespo-Fernandez, E. (2013) Words as weapons for mass persuasion: dysphemism in Churchill's wartime speeches. Text\& talk, 33(3), 311-330. doi 10.1515/text-2013-0014

Creswell, J., W. (2014). Research design qualitative, quantitative, and mixed methods Approaches (4th Ed.). Thousand Oaks, CA: SAGE Publications.

Dubrofsky, R., E (2016). Authentic Trump: Yearning for civility. Television \& New Media, 17(7), 663-666. doi: 10.1177/1527476416652698 
Fairclough, N. (1995). Language and Power. London: Longman.

Flegenheimer M., \& Barbaro M. (2016, November 9). Donald Trump is elected president in stunning repudiation of the establishment. New York Times. Retrieved from http://www.nytimes.com/

Fowler, R. (1991). Language in the news: Discourse and ideology in the press. London: Routledge.

Fowler, R., Hodge, B., Kress, G., \&Trew, T. (1979). Language and control. London: Routledge and Kegan Paul.

Halliday, A., K., \& Matthiessen C. (2004) ( ${ }^{\text {th }}$ ed.). Introduction to functional grammar. London: Edward Arnold.

Hayakawa, S. (1972). Language in thought and action. Chicago: Harcourt Brace Javanovich Hearn, A. (2016). Trump's reality hustle. Television and New Media, 17(7), 656-659. doi:10.1177/1527476416652699

Hughes G. (1998). Words in time: A social history of English vocabulary. Oxford: Blackwell.

Jenkins, K., B., \& Cos, G. (2010). A time for change and a candidate's voice: Pragmatism and the rhetoric of inclusion in Barack Obama's 2008 presidential campaign. American Behavioral Scientists, 54(3), 184-202. doi:10.1177/0002764210381706

Jowett, G., S., \& O'Donnell, V. (2012). Propaganda and Persuasion (5th ed.). Thousand Oaks, CA: Sage Publications.

Lakoff, R. (1973). The logic of politeness: Or, minding your p's and $q$ 's. In C. Corum, T. Cedric.

Smith-Stark, \& A. Weiser (Eds.), Papers from the 9th Regional Meeting of the Chicago Linguistic Society. Chicago Linguistic Society, 292-305.

Milbank, D. (2015, December 1). Donald Trump is a bigot and a racist. Retrieved from https://www.washingtonpost.com

Mcadams, D., P. (2016, June). The mind of Donald Trump. narcissism, disagreeableness, grandiosity-A psychologist investigates how trump's extraordinary personality might shape his possible presidency. The Atlantic. Retrieved from http://www.theatlantic.com/

Nbc News Exit Poll Desk (2016, November 17). Presidential results. http://www.nbcnews.com/

O'Shaughnessy, N., J. (2004). Politics and Propaganda: Weapons of mass seduction. UK: Manchester University Press

Shabo, M., E. (2008). Techniques of propaganda and persuasion. Clayton, DE: Prestwick House.

Volek, B. (1987). Semantic functioning of derived nouns in Russian. Philadelphia: John Benjamins. 
Van Dijk T., A. (1993). Principles of critical discourse analysis. Discourse and society, 4 (2), 249-283.

Van Dijk, T., A. (1995). Discourse analysis as ideology analysis. Retrieved from http://occupytampa.org

Van Dijk, T., A. (1997). What is Political Discourse Analysis. Belgian Journal of Linguistics 11(1), 11-52.

Van Dijk, T., A. (1998) Ideology: A multidisciplinary approach. Retrieved from http://www.discourses.org/

Van. Dijk, T., A. (2000). New(s) racism: A discourse analytical approach", in Ethnic Minorities and the Media: Changing Cultural Boundaries. S. Cottle (Ed). Buckingham: Open University Press.

Van Dijk, T., A. (2006). Ideology and discourse analysis. Journal of Political Ideologies, 11(2), 115-140. Retrieved from http://www.discourses.org/

Wodak. R. (2016). The politics of fear: what right-wing populist discourse mean. Thousand Oaks, CA: Sage Publications 